\title{
DEVELOPMENT OF BILINGUAL POP UP BOOK MEDIA ON JAVANESE PUPPET STORIES FOR ELEMENTARY SCHOOL STUDENTS
}

\author{
Wahyu Dinil Mustaqim \\ Arda Purnama Putra* \\ Tri Murti \\ Primary Education and Preschool, Faculty of Education, Universitas Negeri Malang \\ Jl. Semarang No. 5, Malang, Jawa Timur, Indonesia \\ *E-mail: arda.purnama.fip@um.ac.id
}

Received: August 15, 2020; Accepted: May 30, 2021

\begin{abstract}
This research and development aim to develop bilingual pop-up book media on Javanese puppet stories that valid according to the material experts, media experts, and teachers, as well as practical students. The research uses an ADDIE model with 5 stages, that is analysis, design, development, implementation, and evaluation. The results of validation by the material expert, media expert, and by the user (teacher) sequentially get a percentage of $96,4 \%, 100 \%$, and $95,4 \%$. While the result of the practicality test on the small scale test and the large scale test got a percentage of $93,3 \%$ and $97,5 \%$. Media is categorized as very valid and very practical and can be used for elementary school students.
\end{abstract}

Keywords: bilingual pop-up book media; Javanese puppet stories; ADDIE model; elementary school students

\section{INTRODUCTION}

Indonesia has a variety of different languages in each region. The local language is not only used as the main means of communication, but regional language is also an element of Indonesian culture. One of the regional languages spoken on the island of Java is Javanese. The Javanese language is one of the regional languages that have values of courtesy, literature, manners, and level of speech and contains values of identity, culture, and national identity that need to be preserved. Efforts to preserve the Javanese language have been pursued through the implementation of learning in Javanese language subjects in schools in the 2013 curriculum.

The development of the Javanese language in the 2013 curriculum is stated in Permendikbud Number 79 of 2014 which states that the local content of regional languages is a recommended subject to be included in the 2013 curriculum learning at every level of the basic education unit. The existence of Javanese cultural values needs to be maintained so that they are not lost. Therefore, it 
is necessary to develop a sense of love and awareness of Javanese culture from an early age through learning local content in Javanese language subjects in elementary schools. One of the characteristics of Javanese language learning is that the material presented consists of various levels of speech and storytelling literature which is classified as oral folklore. Oral folklore is part of the Javanese cultural heritage which consists of patriotic stories such as puppet stories, folk tales, various language speeches or language levels, songs or pieces as well as traditional (Kurniati, 2015; Pusparani et al., 2017).

Javanese puppet or wayang stories are one of the popular traditional literary types and have always been synonymous with Javanese society until now. According to Nurgiyantoro (2011), wayang is an epic that tells the story of the heroism of good characters facing and destroying bad characters. Wayang stories in ancient times were usually used as a means of conveying messages, preaching, arts and learning. The presentation of wayang stories in learning is very important because wayang internalizes good character values. The story of wayang stories can be appointed as a teaching material in schools that can be used to convey moral messages to students. The same thing was also expressed by (Kurniati, 2015) which states that, with Javanese language teaching material based on wayang stories, it can train communication in regional languages, culture, and with the character of love for culture.

Based on observations made at SDN 06 Demuk Kab. Tulungagung on 11 to 13 December 2019 in learning Javanese, it was found that there was a problem in the process of implementing Javanese language learning, especially in puppet story material. From observations, it is known that Javanese language learning is still dominated by using the method of lectures, question, and answer, and assignments in story text material, students are less independent in learning, on average grade $\mathrm{V}$ students have difficulty understanding the description of the text of wayang stories, so the teacher has to repeatedly explain again to translate the story text into simpler language or translate into Indonesian so that it is easy for students to understand. In addition, the implementation of learning on the text material of wayang stories is not optimal, the media used in learning is still limited to media in the form of reading texts in the Javanese Tantri Basa package book.

Students in the interview also said that the textbook was not attractive because there were very few pictures, the presentation of the text for reading wayang stories which generally used a lot of Kawi uptake was also found to be very difficult for students to understand. So that learning Javanese using this textbook is considered less interesting and boring. According to the fifth-grade teacher, optimizing Javanese language learning that can foster students' interest in Javanese culture is considered very important. This is also influenced by the current background of students who have a low interest in Javanese culture, especially about wayang culture. Students' awareness of the importance of good character values at school is still lacking, and there is an opinion regarding 
puppet story material that is boring and is not considered very important. This can lead to the waning of the love of the motherland in students.

Love for the motherland can be interpreted as a way of thinking, acting, and having an insight that places the interests of the nation and the state above the interests of self and groups. Meanwhile, according to the Ministry of National Education, the Research and Development Center for Curriculum 2010 defines love for the country as a way of thinking, behaving, and acting that shows loyalty, concern, and high respect for language, the physical, social, cultural, economic and political environment of the nation. One form of love for the country is to protect the nation's cultures in the surrounding environment, including the Javanese language. Javanese language plays a role in preserving the nation's cultural heritage, and can strengthen the character of love the nation (Rohmah et al., 2020; Saddhono \& Rohmadi, 2014; Tanaya \& Adriani, 2016).

Departing from these problems, it is necessary to develop puppet story learning media by strengthening the character of love for the country in the material. Considering the characteristics of the puppet play material which are still classified into the realm of stories or types of oral folklore, the use of pop-up book media that can illustrate images and interestingly explain story texts is considered very suitable. Pop-up is a medium in the form of a book where when the page is opened, pulled, or lifted, a level will appear with a three-dimensional impression (Devi \& Maisaroh, 2017). Pop-ups consist of various folds that are taped and then moved so that the pop-ups can open, close, appear and not fold when the pop-up is opened. The advantages of pop-up books are: (1) attracting and directing students' attention into teaching and lesson content, (2) providing a sense of comfort in the teaching process, (3) facilitating the achievement of goals to understand and remember information and messages contained in images and the latter, and (4) provide a context for understanding the text for students who are weak in reading to organize information in the text and recall it (Arsyad, 2014; Pratiwi et al., 2020).

Agree with Devi \& Maisaroh (2017) who revealed that pop-up books are very easy to adjust, create and innovate, and are suitable if applied in learning puppet story material on local content in local languages in elementary schools. In addition, the characteristics of the pop-up book display itself that can be moved, arose, have a texture, especially with the visualization of a realistic 3dimensional space, of course, can make the packaged wayang stories more interesting and less boring for students.

This pop-up book media contains the "Kumbakarna Gugur" puppet material. This material is adjusted to basic competencies understand, and identify the text of wayang stories. Based on Permana (2019) in the wayang play "Kumbakarna Gugur", it is taken from the epic story of the Ramayana puppet (Javanese: Ramasinta), which tells the love story of Rama's struggle to seize Shinta (Rama's wife) from the Giant King Benama Rahwana. In the play "Kumbakarna Gugur", it 
is told that Kumbakarna is a puppet character in the form of a giant, large and tall, and has 3 siblings. Even though Kumbakarna was a giant, he had a good mind, Kumbakarna had a chivalrous character and did not want to defend his own brother's crimes.

This can also be seen from Kumbakarna's attitude when he learned that his brother (King Rahawana) intended to kidnap the goddess Shinta from Rama (Sri Rama). Kumbakarna was sent to kidnap Dewi Shinta but he strongly refused, he strongly disagreed with his brother's intention, reason, and attitude to kidnap Dewi Shinta, finally, Rahwana ordered his subordinates to go to kidnap Dewi Shinta, as a result of Rahwana's evil intentions to kidnap Shinta (Kamajaya, 1985). Finally, there was a riot, a war broke out between the giant nation of Alengka, which was attacked by an army of monkeys led by Sri Rama, Dewi Shinta's husband.

Rahwana is cunning and does not lose his mind, he incites Kumbakarna who refuses by telling the condition of his family, nation, and homeland which is now destroyed, Kumbakarna cannot allow seeing his hometown and nation being destroyed finally goes to war. It is necessary to remember that the decline of Kumbakarna in the war was not because of defending his brother but because of his obligation to defend and protect the nation of his homeland. The spirit of defending the country in the character of the Kumbakarna character can be a good role model amid the declining attitude of love for the country and the nation (Cahyono, 2015). The value of character education and exemplary in the character of kumbakarna figures can be emulated by the younger generation and is very suitable to be appointed in learning at school.

The puppet material pop-up book media is also designed with a bilingual presentation, namely by using Javanese and Indonesian languages, so that readers will be easier to read pop-up book media offerings. That way the pop-up book media can foster interest in reading and be able to support students' understanding of the puppet story material which students assess as an insignificant and boring subject. The purpose of this research and development is to produce pop-up media for puppet storybooks for class V A students at SDN Demuk 06 that are practical for students, valid according to material experts, and media experts and users.

\section{METHOD}

The development of the bilingual puppet storybook pop-up media was carried out in grade V SDN 6 Demuk, Tulungagung Regency. The research carried out followed the steps of the ADDIE development model. There are 5 stages of development using the ADDIE model, namely: (1) analysis, (2) design, (3) development, (4) implementation, and (5) evaluation. (Tegeh et al., 2014).

The analysis stage is carried out through observation and interviews to determine gaps, needs, and problems in Javanese learning in grade $\mathrm{V}$ elementary school, then analyzed to obtain problem-solving solutions. The design stage is carried out by compiling an outline of a development 
plan which includes the design of the right media, materials, and strategies so that the resulting product is effective. The development stage is carried out by translating the design specifications into physical form, and producing a development product prototype before the trial is carried out. This stage involves collecting all sources or references needed in developing the material, making illustrations, storyboards or layouts and after the initial product is desired, it is then validated by the experts. The implementation stage is carried out in two stages, namely a small scale and a large scale to determine the practicality of the product. Furthermore, the evaluation stage is carried out in the form of formative and summative evaluation. Formative evaluation is carried out to collect data at each stage which is used to improve the pop-up book media. Summative evaluation is carried out in the final stage to determine its effect on student learning outcomes, the percentage of needs and the feasibility of the puppet story pop-up book products, and the benefits when used by users.

The research data was obtained through data collection based on the results of interviews, observations, and assessment questionnaires of material experts, media experts, users, and student response questionnaires. The data analysis technique used to analyze the questionnaire data was quantitative, for data in the form of suggestions and input were analyzed qualitatively. Quantitative data were analyzed from validation questionnaire data from material experts, media experts, teachers, and student responses. The questionnaire whose value has been obtained is then processed using the validation formula which refers to (Akbar, 2013; Krismon et al., 2020).

$V a h=\frac{T s e}{T s h} \times 100 \%$

Information:

Vah $=$ expert validation

Tse $=$ total score achieved

$\mathrm{Tsh}=$ total expected score

The calculation results will be interpreted according to the presentation in Table 1 .

Table 1. Criteria for validation results

\begin{tabular}{cll}
\hline Achievement Level (\%) & \multicolumn{1}{c}{ Category } & \multicolumn{1}{c}{ Test Decision } \\
\hline $85,01-100,00$ & Very valid & Can be used without revision \\
$70,01-85,00$ & Valid & Can be used, but needs minor revision \\
$50,01-70,00$ & Less valid & Can be used with major revisions \\
$01,00-50,00$ & Not valid & Not allowed to be used \\
\hline
\end{tabular}

Source: (Akbar, 2013; Krismon et al., 2020)

Based on Table 1, it can be concluded that the pop-up book can be said to be valid if it gets a minimum value of $70 \%$. If it is less than $70 \%$, a lot of revisions are needed based on suggestions and input from media experts, material experts, teachers, and students as users. The questionnaire used for students uses the Guttman scale. According to Sugiyono (2008), the Guttman scale gives a 
"yes-no" answer with a score of 1 on the answer "yes" and a value of 0 on the answer no. The results of the questionnaire were then analyzed using the formula from (Putra et al., 2019; Yamasari, 2010) as follows:

$P=\frac{X i}{X \max } \times 100 \%$

Information :

$\mathrm{P}$

$=$ Percentage of score

$\mathrm{Xi} \quad=$ The number of scores selected

$\mathrm{Xmax} \quad=$ Total maximum score

Based on the results of data analysis from each respondent, then interpreted according to Table 2.

Table 2. Criteria of Attractiveness and Practicality

\begin{tabular}{lll}
\hline Achievement Level (\%) & \multicolumn{1}{c}{ Category } & \multicolumn{1}{c}{ Test Decision } \\
\hline $76 \leq \mathrm{P} \leq 100$ & Very interesting / very practical & Can be used without revision \\
$51 \leq \mathrm{P} \leq 75$ & Interesting / practical & Can be used, but needs minor revision \\
$26 \leq \mathrm{P} \leq 50$ & Less attractive / less practical & Can be used with major revisions \\
$0 \leq \mathrm{P} \leq 25$ & Not attractive / impractical & Not allowed to be used \\
\hline
\end{tabular}

Source: (Putra et al., 2019; Yamasari, 2010)

Based on the criteria in Table 2, the media can be applied in learning if the percentage results of attractiveness and practicality can reach values above $50 \%$. If the percentage results of the media have not reached the value of $50 \%$, then a major revision must be made to the media.

\section{RESULT AND DISCUSSION}

The resulting product is a bilingual puppet storybook pop-up media for grade $\mathrm{V}$ elementary school students. The pop-up book consists of a book cover and contents. The pop-up book is made using A4 paper measuring $21 \mathrm{~cm}$ x $29 \mathrm{~cm}$. This media contains images of colored puppets which are cut out and pasted on a book sheet. The text of the wayang stories uses two languages, namely Javanese and Indonesian. The material for the wayang story plays presented in the pop-up book media is the wayang play taken from the epic Ramayana puppet story which tells the play of a giant character named Kumbakarna. The pop-up book was developed using Corel Draw X4, Photoshop CS 5, and Microsoft Word 2013 software. The contents of the pop-up book were prepared using a combination of art paper, ivory 260 , and construction paper.

The pop-up book media that have been made are then validated by material experts, media experts, and teachers. The results of the validation by material experts are presented in Table 3 .

Table 3. Data on Material Expert Validation Results

\begin{tabular}{cclccc}
\hline No. & \multirow{2}{*}{ Aspect } & \multicolumn{1}{c}{ Indicator } & $\begin{array}{c}\text { Maximum } \\
\text { Score }\end{array}$ & Score & Comment \\
\hline 1. & Language & Writing Accuracy & 4 & 4 & - \\
& & Accuracy of sentences & 4 & 4 & -
\end{tabular}




\begin{tabular}{|c|c|c|c|c|c|}
\hline No. & Aspect & Indicator & $\begin{array}{c}\text { Maximum } \\
\text { Score }\end{array}$ & Score & Comment \\
\hline \multirow{3}{*}{2.} & \multirow{3}{*}{ Contents } & Readability & 4 & 4 & - \\
\hline & & Conformity of material & 4 & 4 & - \\
\hline & & Material Coverage & 4 & 4 & - \\
\hline \multirow[t]{2}{*}{3.} & \multirow{2}{*}{$\begin{array}{c}\text { Presentation of } \\
\text { material }\end{array}$} & Description of Material & 4 & 4 & - \\
\hline & & Presentation of Material & 4 & 3 & - \\
\hline \multicolumn{2}{|c|}{ Total Score } & & 28 & 27 & - \\
\hline \multicolumn{2}{|c|}{ Percentage Score } & & $96,4 \%$ & & \\
\hline
\end{tabular}

Based on Table 4, it can be seen that the results of the media assessment by material experts get an average percentage of $96.4 \%$, which is included in the interval achievement of $85.01 \%$ $100.00 \%$, with the very valid category. So that the test decision shows that the media product can be used without revision. After it is validated by material experts, then the pop-up book media is validated by media experts. The results of the media expert validation can be seen in Table 4 .

Table 4. Validation Results of Media Experts

\begin{tabular}{lllccc}
\hline No. & \multicolumn{1}{c}{ Aspect } & \multicolumn{1}{c}{ Indicator } & $\begin{array}{c}\text { Maximum } \\
\text { Score }\end{array}$ & Score & Comment \\
\hline 1. & Presentation & Text legibility & 4 & 4 & - \\
& of media & Use of media & 4 & 4 & - \\
2. & Display & Image illustration & 4 & 4 & - \\
& & Development of media & 4 & 4 & - \\
\hline & forms & & & $\mathbf{8}$ \\
\hline \multicolumn{2}{r}{ Percentage Score } & & $\mathbf{8}$ & $\mathbf{1 0 0 \%}$ \\
\hline
\end{tabular}

The results of the validity calculation from table 4 show that the Media Product Media Pop-Up Book Bilingual Puppet Stories achieves a result of $100 \%$. So that it can be interpreted that the product is very valid, so that the test decision shows that the media product can be used without revision so that the test decision shows that the media product can be used without revision. After the media has been declared its validity by material experts and media experts, then it is validated by the teacher (user) before finally being tested on students. The results of the validation by the teacher (user) are presented in Table 5.

From the results of user validation in Table 6 , after the quantitative data were analyzed, the results of the validity calculation reached a percentage of $95.4 \%$ with a very valid category. So that the bilingual pop-up book media product can be used immediately without revision. Qualitative data obtained from suggestions and input by users of the bilingual Pop-Up Book Media product, namely, input to add a list of references to the bilingual Pop-Up Book Media media.

After the media was revised based on suggestions from material experts, media experts, and teachers as users, then the media was tried out on students. The trial was carried out twice, namely the small-scale test and the large-scale test. Based on the results of student questionnaires, it is known that the results of student questionnaires on small-scale trials obtained a percentage of $93.3 \%$, and in large-scale trials obtained a percentage of $97.5 \%$. The score falls into the very practical / very 
interesting category and can be used without revision.

Based on the results of validation by material experts, media experts, and users, the pop-up book media is valid and practical for use in learning. Material expert validation includes three aspects of assessment, namely language, content, and presentation of the material. There are suggestions to bring out the love of the country more in the wayang material. This is following the opinion of Ibda (2017) that the method used to convey messages uses symbolic Javanese narrative characteristics, so that messages can be conveyed by highlighting characters that can represent the content of the message. This opinion is in line with Permana (2019) where the value of education for the character of love for the country in the wayang Kumbakarna story can be learned from the Kumbakarna character who has been considered an evil character, in fact, is a giant character who has determination and is willing to sacrifice himself to defend his country. The results of validation by material experts get the percentage of results of $96.4 \%$. These results are categorized as very valid so that the test decision on the bilingual puppet storybook pop-up media can be used without revision.

Table 5. User Validation Results Data

\begin{tabular}{|c|c|c|c|c|c|}
\hline No. & Aspect & Indicator & $\begin{array}{l}\text { Maximum } \\
\text { Score }\end{array}$ & Score & Comment \\
\hline \multirow[t]{3}{*}{1.} & \multirow[t]{3}{*}{ Language } & Writing Accuracy & 4 & 4 & - \\
\hline & & Accuracy of sentences & 4 & 4 & - \\
\hline & & Readability & 4 & 4 & - \\
\hline \multirow{2}{*}{2.} & \multirow{2}{*}{ Contents } & Conformity of material & 4 & 4 & - \\
\hline & & Material Coverage & 4 & 4 & - \\
\hline \multirow[t]{2}{*}{3.} & \multirow{2}{*}{$\begin{array}{l}\text { Presentation of } \\
\text { material }\end{array}$} & Description of Material & 4 & 4 & - \\
\hline & & Presentation of Material & 4 & 4 & - \\
\hline \multirow[t]{2}{*}{4} & \multirow{2}{*}{$\begin{array}{l}\text { Presentation of } \\
\text { media }\end{array}$} & Text legibility & 4 & 4 & - \\
\hline & & Use of media & 4 & 3 & - \\
\hline \multirow[t]{3}{*}{5} & \multirow[t]{2}{*}{ Display } & Image illustration & 4 & 4 & - \\
\hline & & Development of media forms & 4 & 3 & $\begin{array}{l}\text { Provide a list } \\
\text { of material } \\
\text { references to } \\
\text { the media }\end{array}$ \\
\hline & Total Score & & 44 & 42 & - \\
\hline \multicolumn{2}{|c|}{ Percentage Score } & & & $95,4 \%$ & \\
\hline
\end{tabular}

Media validation includes 2 aspects of assessment, namely media presentation and appearance. The results of the calculation of the validity of the media get a score of $100 \%$, this percentage result is in the very valid category, so that the bilingual puppet storybook pop-up media product can be used without revision. The results of this media validation have been very good when viewed from previous developments by Rohmah et al. (2020) in the form of wayang storybook media which is similar to the results of media validation which reached a percentage of $90 \%$. As for comments from media experts, pop-up media is very interesting and useful to add to the literature, especially for the Javanese language. This comment is in line with the advantages of pop-ups conveyed by Dyk \& Ruiz et al. (Safitri \& Sudarsono, 2019) who argued that pop-up books are one of the visual media 
that can attract students' interest in reading, are fun and interesting for people from all ages to read it.

User validation was carried out by a class teacher of Javanese class V SDN 06 Demuk Kab. Tulungagung. The assessment aspects include aspects of language, content, presentation of material, presentation of media, and appearance. Based on the calculations that have been made from the validation, the validity of the bilingual puppet storybook pop-up media by the teacher as a user validator obtained a percentage of $95.4 \%$. This percentage result falls into the very valid category and can be used without making revisions. The results of this user validation are quite good because, in the development of the previous wayang story media by (Rohmah et al., 2020), the percentage results of user validation were $97 \%$.

The comments given by users to the Media Pop-Up Book of Bilingual Puppet Stories, namely, the packaging of wayang story material into pop-up forms is very interesting and also easy to use in learning and outside learning. This is also expressed by the opinion of (Silberman, 2010), where pop-ups are book media that are usually used in conveying story texts or learning materials with the characteristics of highlighting graphic visualization so that the information inside is easier to capture and apply by beginners and experts alike.

Small-scale trials are carried out to minimize errors before large-scale trials are carried out. Small-scale trials were carried out with elementary students around the residence. The results of the small-scale trial assessment obtained a practicality value of 93.3\%, with the very practical category, and can be used without any revision. The input given when conducting a small-scale trial was the addition of an empty back cover. In addition, students' responses that were conveyed through comments on the pop-up media of bilingual puppet storybooks were also very positive, namely Indonesian language offerings and material packaged in the media made it easier for readers, and readers were more interested in reading wayang stories in this media than based media. other print.

Large-scale trials are carried out after the product has undergone refinement. The results of the large-scale trial received a free value of $96.6 \%$, with the category very practical and can be used without revision. Based on the results of large-scale trials, several findings were obtained, among others, (1) students were very enthusiastic and enthusiastic about learning part by part of the material contained in the bilingual puppet storybook pop-up media, (2) students also easily remembered the material presented because The display of the story text in the media is equipped with illustrative images that help the ability to think and reason, this can be seen in the discussion and question and answer process after the trial is carried out.

The use of bilingual puppet storybook pop-up media in Javanese language trials and learning activities can encourage students to learn independently and directly interact with learning resources. The source of learning here is the Javanese wayang culture, as confirmed by the opinion of (Kurniati, 
2015), namely, the use of wayang story teaching materials in Javanese language learning is a form of cultural conservation that reflects indicators of strengthening the value of the character of love for the country in the form of upholding and preserving indigenous Indonesian culture.

\section{CONCLUSION AND SUGGESTION}

\section{Conclusion}

The resulting product is a practical and valid bilingual pop-up storybook media. The results of validation by material experts, media experts, and users respectively obtained a percentage of $96.4 \%$, $100 \%$, and $95.4 \%$, so it means that all three falls into the very valid category, with the decision to test the product, can be used without revision. The practicality value according to the students, respectively, got a percentage score of $93.3 \%$ and $96.6 \%$, which means that the pop-up book media is very practical and interesting to use in learning. So that based on these values, a decision can be made that the pop-up book media is suitable for use without revision.

\section{Suggestion}

Further research and development of this product, pop-up media for bilingual Javanese puppet or wayang stories can be developed for other materials. The material in this media is only limited to one wayang story play. Considering that there are many kinds of regional wayang stories that educate and are suitable for strengthening character values, so that the wayang story material in this media can be developed according to the problems and needs of students in learning and foster interest students to learn about local culture related to wayang.

\section{REFERENCES}

Akbar, S. (2013). Instrumen perangkat pembelajaran. Bandung: PT Remaja Rosdakarya.

Arsyad, A. (2014). Media Pembelajaran. rev. ed. Jakarta: Raja Grafindo Persada.

Cahyono, B. (2015). Nilai pendidikan karakter dalam serat tripama dan relevansinya dengan pembelajaran apresiasi sastra jawa (kajian heuristik dan hermeneustik). UNS (Sebelas Maret University).

Devi, A. S., \& Maisaroh, S. (2017). Pengembangan Media Pembelajaran Buku Pop-Up Wayang Tokoh Pandhawa pada Mata Pelajaran Bahasa Jawa Kelas V SD. Jurnal PGSD Indonesia, 3(2).

Ibda, H. (2017). Media Pembelajaran Berbasis Wayang: Konsep dan Aplikasi. CV. Pilar Nusantara. Kamajaya. 1985. Tiga Suri Teladan. Yogyakarta : U.P. Indonesia.

Kementerian Pendidikan. 2010. Pengembangan pendidikan budaya dan karakter bangsa pedoman sekolah. 124.

Krismon, F. H., Zainuddin, M., \& Putra, A. P. (2020). Pengembangan LKPD Berbasis Swishmax Materi Peristiwa Mengisi Kemerdekaan dengan Penguatan Karakter Tanggung Jawab di Kelas V. Wahana Sekolah Dasar; Vol 28, No 2 (2020)DO - 10.17977/Um035v28i22020p068 . http://journal2.um.ac.id/index.php/wsd/article/view/14249

Kurniati, E. (2015). Implementasi Pembelajaran Bahasa Jawa SD yang Integratif Komunikatif Berbasis Folklore Lisan sebagai Wujud Konservasi Budaya. Jurnal Penelitian Pendidikan, 
$32(2)$.

Nurgiyantoro, B. (2011). Wayang dan pengembangan karakter bangsa. Jurnal Pendidikan Karakter, $1(1)$.

Permana, Y. (2019). Karakter dalam Cerita Wayang Kumbakarna Gugur. PANTUN, 2(1).

Pratiwi, Y. D., Bintartik, L., \& Putra, A. P. (2020). Development of POE Learning Model-Based Booklet for Elementary School. 277-284. https://doi.org/10.2991/assehr.k.201214.249

Pusparani, H., Samsudi, S., \& Haryadi, H. (2017). The Analysis of Requirements Developing Teaching Materials in Writing Folklore with Javanesse Language Based on Local Wisdom. Journal of Primary Education, 6(2), 94-102.

Putra, A. P., Nawawi, I., Badawi, A., Sutarno, Pratiwi, I., Kim, J., Untari, E., \& Umaroh, M. (2019). Interactive Multimedia Analysis in Thematic Learning: A Study of Practical Aspect. 2019 5th International Conference on Education and Technology, ICET 2019. https://doi.org/10.1109/ICET48172.2019.8987218

Rohmah, A. M., Untari, E., \& Murti, T. (2020). Pengembangan cerita wayang (riyang) bergambar berbasis karakter gemar membaca bahasa Jawa untuk siswa kelas IV sekolah dasar. Wahana Sekolah Dasar, 27(2), 38-46.

Saddhono, K., \& Rohmadi, M. (2014). A Sociolinguistics Study on the Use of the Javanese Language in the Learning Process in Primary Schools in Surakarta, Central Java, Indonesia. International Education Studies, 7(6), 25-30.

Safitri, K., \& Sudarsono, S. (2019). Developing a pop up book supportive to narrative-texts teaching. Journal of English Language Teaching Innovations and Materials (JELTIM), 1(2), 66-72.

Silberman, M. (2010). 101 cara pelatihan dan pembelajaran aktif. Jakarta: Indeks.

Sugiyono. (2008). Metode penelitian pendidikan:(pendekatan kuantitatif, kualitatif dan $R \& D$ ). Alfabeta.

Tanaya, D., \& Adriani, M. (2016). Dictionary-based Word Segmentation for Javanese. Procedia Computer Science, 81(May), 208-213. https://doi.org/10.1016/j.procs.2016.04.051

Tegeh, I. M., Jampel, I. N., \& Pudjawan, K. (2014). Model penelitian pengembangan. Yogyakarta: Graha Ilmu.

Yamasari, Y. (2010). Pengembangan media pembelajaran matematika berbasis ICT yang berkualitas. Seminar Nasional Pascasarjana X-ITS, Surabaya, 4. 